\title{
Apology Strategies Employed by Saudi EFL Teachers
}

\author{
Marzouq Nasser Alsulayyi \\ Anglia Ruskin University, England, UK \\ E-mails: marzouqnasser@hotmail.com
}

Doi:10.7575/aiac.alls.v.7n.6p.70

Received: 04/08/2016

URL: http://dx.doi.org/10.7575/aiac.alls.v.7n.6p.70

Accepted: 09/10/2016

\begin{abstract}
This study examines the apology strategies used by 30 Saudi EFL teachers in Najran, the Kingdom of Saudi Arabia (KSA), paying special attention to variables such as social distance and power and offence severity. The study also delineates gender differences in the respondents' speech as opposed to studies that only examined speech act output by native and non-native speakers of English. To this end, the study employs a Discourse Completion Task (DCT) that consists of 10 situations designed to test how the respondents would react if they imagine that they belong to different types of social status whether higher, lower or equal. In addition, social distance and power have been taken into consideration in designing the ten situations included in the test used in this study. The results reveal that Illocutionary Force Indicating Device (IFID) is the most used apology strategy by the Saudi respondents followed by downgrading responsibility (DR), upgrader, offer of repair, taking on responsibility and then verbal redress. The results also reveal that gender has a great impact on the use of apology strategies in various ways. For instance, the IFID strategy and the upgrader strategy are used by males more than their female counterparts, whereas females use the DR strategy more than their male counterparts. It has been argued that some of the respondents' answers to the test were influenced by their mother tongue, as reported in previous studies conducted on apology strategies. The study discusses the results elicited via the DCT and compares them with those of previous studies on apology strategies and other speech acts. Finally, the study concludes with recommendations for further research.
\end{abstract}

Keywords: pragmatics, apology strategies, Saudi EFL teachers, interlanguage pragmatics, target culture

\section{Introduction}

In the realm of second language learning, the cultural and social aspects of English as a target language have a paramount importance on the success of that process. Second language learners need to attain the pragmatic and cultural competence of English through understanding the linguistic functions of English (Demeter, 2006). The main purpose of learning English just like any other language is to communicate effectively, using appropriate language (Altakhaineh \& Rahrouh, 2015). Therefore, it is imperative for L2 learners to master the proper use of English speech acts in various contexts. This is the main concern of pragmatics according to Levinson (1983:21), he posited that "Pragmatics is the study of the relation between language and context that are basic to an account of language understanding." In this concern, Blum- Kulka, Olshtain and Cohen, (1984) explained that the concept of appropriateness differs from one language to another based on the difference between the different cultures of these two languages (see also Altakhaineh \& Zibin, 2014). In this regard, one may observe that the investigation of English apology strategies used by EFL learners is constantly marked by interlanguage pragmatics, which is mainly attributed to what is known as pragmatic transfer between the mother tongue and the target language, as shown by Qorina's (2012) study which demonstrates the transfer of Indonesian language into the pragmatics output. Thijittang's and Le's (2010) study also shows that the interlanguage pragmatics of Thai native speakers of English are highly dominated by the influence of social factors related to the social distance, social status and the degree of offence severity. The influence of the respondents' mother tongue on their use of the foreign/second language can be observed when these respondents' use speech acts. Austin (1975) stated that speech acts, as compared to other aspects of language, are the most culturally related aspects. Although there are various definitions of speech acts, they are generally viewed as utterances accompanied with action performance. According to Yule (1996), an apology comes under the expressive type of speech act. As one of the speech acts, apology is defined in various ways (Fraser, 1981; Holmes, 1989; Trosborg, 1995; Bataineh, 2005 among others). Holmes (1989: 196) explained that apology is "a speech act addressed to V's face-needs and intended to remedy an offence for which A takes responsibility, and thus to restore equilibrium between $\mathrm{V}$ and $\mathrm{A}$ (where $\mathrm{A}$ is the apologist, and $\mathrm{V}$ is the victim or person offended)". In addition, Bataineh (2005: 4) explained that apology strategies are "the methods used by individuals to perform the speech act of apology". Al-Sobh (2013) clarified that EFL Arab learners may be in difficulty whenever they fail to successfully communicate with English native speakers. Their failure can be attributed to their unawareness and familiarity with English cultural values and politeness norms. Thus, a feeling of unfriendliness may prevail between the Arab EFL speakers and English native speakers due to this failure. Following this line of thought, the present study aims to investigate the use of apology expressions by Saudi EFL teachers. It also measures the effect of gender on the participants' use of apology strategies in English. 


\subsection{Apology strategies}

There are several ways of classifying apology strategies (e.g. Fraser, 1981; Trosborg, 1987; Bergman \& Kasper, 1993; Brown \& Attardo, 2000; Bataineh \& Bataineh, 2006). The apology strategies proposed by Fraser include apology obligations of the offender, the offender's offer to apologize, offender requests to the offended hearer to accept his/her apology, expressions of regret, asking for forgiveness, acknowledging his/her responsibility, promising forbearance and situations where the offender offers redress. Trosborg has classified apology strategies into six categories, namely, minimizing offence, acknowledgment of the offence, types of explanation (implicit and explicit), offers of repair, promises of forbearance and expressions of concern. Bataineh et al. have proposed five categories of apology strategies: Illocutionary Force Indicating Device (IFID), responsibility expressions, statements of account, offers of repair and promises for forbearance. The current study adopts the six apology strategies proposed by Bergman and Kasper (1993). These strategies include the following:

- Illocutionary Force Indicating Device (IFID):

Blum-Kulka and Olshtain (1998) explained that IFID is an apology strategy which explicitly expresses regret by using means like 'sorry', 'forgive me', excuse me', 'I regret', and so on. IFIDs highlight the speaker's need to seek forgiveness by overtly expressing his/her regret over an action that violates the hearer. In this regard, Bergman and Kasper (1993: 88) give an example of the IFID strategy: speaker A forgets to bring back the book which he borrowed from speaker B. Speaker A apologizes by saying "I'm sorry. I forgot to bring your book". Here, speaker A explicitly expresses his/her regret by using the word 'sorry' as a means of compensation for his/her wrongdoing.

- Upgrader and apology strategies:

Upgrader refers to words that add to the power of the apologetic expressions like 'so, very, and terribly'. In this respect, Bergman and Kasper (1993: 88) mention an illustrative example where a student fails his/her examination because the professor misplaces his/her examination paper. Upon finding out that the student failed because of his fault, the professor apologizes by saying "I'm terribly sorry. I don't know where I put it".

- Taking on responsibility:

In this strategy, the apologizer exerts effort to make up for his/her fault by taking verbal and non-verbal actions. This strategy can be divided into three sub-categories, namely, expressions of self-blame, expressions of lack of intent and expressions of admission of fact (Cohen \& Olshtain, 1981). Regarding the first sub-category of taking on responsibility (i.e. expression of self-blame), Bergman and Kasper (1993: 88) give the following example: the waiter offends a customer and exerts efforts to repair his fault by blaming himself and saying "How stupid of me to do that". In the second sub-category (i.e. expression of lack of intent), Bergman and Kasper (1993: 88) use the following example: "at a restaurant, a waiter spills food on a customer's clothes". The waiter apologizes by clarifying that the offence occurred unintentionally by saying "I did not mean to do that". As for the third type of strategy (i.e. expression of admission of fact), Bergman and Kasper's (1993: 88) provide the following example: "a professor has not yet graded a term paper that a student was supposed to pick up". As an apologetic expression the professor admits the fact and says "I haven't graded it yet".

\section{- Downgrading responsibility or the severity of the offence}

This refers to the speaker's utterance to reduce his/her accountability for the offence. It is expressed by various strategies, such as excuse, justification, claiming ignorance, problematizing a precondition, denial, and reducing the severity of the offence. As an example of using an excuse, a manager claims that her watch had stopped as an excuse for being late for a meeting in her office and says "My watch had stopped". With regard to justification, speaker A meets his friend B but he has to leave for a meeting, so he says "I was suddenly called to a meeting, I have to go now". An example of claiming ignorance is if speaker A invites all his friends including his close friend speaker B to a party. However, B does not go to A's house and instead claims ignorance about the party by saying "I didn't know that you were expecting me". An example of problematizing a precondition might be where speaker A is to meet his friend for coffee at 11 . However, he does not show up until 12 o'clock. He claims that they were not supposed to meet before 12 o'clock and says, "We were not supposed to meet before 12". Regarding denial, Bergman and Kasper (1993:88) provide the following example: at an airport, a customs official messes up a traveler's suitcase. He says, "I didn't do it, I do not know where the suitcase is". The denial of the customs official's responsibility for the fault leads to blaming someone else. An example of reducing the severity of the offence might be where a manager comes late to attend a meeting; he attempts to reduce the severity of his fault by saying "I'm only 10 minutes late".

\section{- Offers of repair}

In such a strategy, the offender, according to Cohen and Olshtain (1981), attempts to repair damage resulting from his/her fault. This repair can have a literal sense or may come in the form of payment to compensate the victim of that fault when actual repair is impossible. An example of this strategy would be if speaker A has damaged the car, which he borrowed from his friend B. Speaker A apologizes by saying "I will pay for the damage". 
This simply means showing concern for the victim of the offence. For example, speakers A and B are at the coffee shop. Speaker A spills speaker B's coffee accidentally. Then, A says, "Let me buy you another drink". The next section reviews some studies that examined the use of apology strategies by Arab speakers of English.

\subsection{Studies on Arab speakers of English using apology strategies}

Al-Sobh (2013) analyzed apology strategies in light of the politeness strategies employed in various situations by eight native speakers of Arabic. The Jordanian respondents are English undergraduates at Irbid National University, Jordan. The research found that the respondents tend to use the Arabic equivalents of the English intensifiers like 'so' and 'very' in their apologetic expressions whenever their interlocutors held higher positions than them such as lecturers. However, their apologetic expressions were free of such intensifiers in less formal situations or when addressing equal status interlocutors and relatives. In other words, the adoption of apology strategies among these respondents varied according to the different situations and interlocutors. On the other hand, Bataineh and Bataineh (2006) studied the influence of gender on the intercultural apology strategies adopted by speakers of the same language but with different dialects. They reported that Jordanian speakers of Arabic, whether males or females, tended to vary in their use of English apology strategies. This variation can be noted in the Jordanians' adoption of various primary apology strategies like expressions of regret, accounting for the offence and promising not to do such a thing again. Jordanians, as reported by Bataineh and Bataineh (2006), adopt non-apologetic strategies such as blaming the offended people and lessening the importance of the offence. Whereas females may tend to ignore the offence itself in order not to be engaged in a discussion over it, males tended to downgrade their responsibilities by blaming their interlocutors. In this regard, Bataineh and Bataineh (2006: 1910) suggested that:

Much sociolinguistic research has been conducted on gender differences in speech act realization. Empirical findings seem to suggest that gender differences do exist in politeness, so much so that women are considered to be more polite, less critical, and prone to using more softening devices than are men.

Bataineh and Bataineh (2006) pointed out as well that some researchers like Cameron (1997) are neither in favor of apology strategies variation nor cultural differences based on gender.

Similarly to Al-Sobh' study, Nureddeen (2008) investigated how Sudanese speakers of Arabic use apology strategies in their mother tongue. Data were collected from 110 Sudanese graduates (55 males and 55 females) and analyzed in terms of offence severity, social distance and power. Nureddeen reported that the respondents tend to select apology strategies based on the cultural impact of using Arabic. Nureddeen emphasized the important effect of 'intercultural or pragmatic competence' in using a language. A language should be used in accordance with the norms, values, and pragmatic rules which the native speakers of that language follow whenever they use that language. Nureddeen found that the use of IFID strategies varies according to the social distance of the speaker and hearer. For example, Nureddeen (2008: 288) stated that the highest frequency of using IFID strategies is in distant relation situations, while "the lowest frequency was supplied for situations 1 (car damage, 47\%) and 3 (failed student, 30\%). More IFIDS were provided for Situations 5 (wrong office, 95\%), 2 (damaged magazine, 64\%) and 4 (borrowed book, 62\%)". The Sudanese respondents usually start and end their apology expressions with IFID strategies while using other strategies in between. Final IFID strategies are used by the Sudanese to express their sincere apologies in connection to serious offence situations and to reflect their sympathy with their hearers. As for taking responsibility, Nureddeen found that the percentage of that strategy's use reflects low frequency as it is used in situations that involved perceived seriousness like delayed messages, damaged cars, borrowed money and so on. With regard to offers of repair, the Sudanese respondents only made that offer with high frequency in three situations, namely: failed student, borrowed book, and damaged car, while in other situations their frequency percentage is very low (ranging from zero to four per cent). It is likely that verbal redress and offence minimization also have low frequencies among the Sudanese apologetic expressions.

The literature review demonstrates that some researchers have investigated apology strategies employed by Arab speakers of English, especially Jordanian and Sudanese. However, no study, to the best of my knowledge, has investigated the use of apology strategies by Saudi EFL speakers, in general, and teachers, in particular, paying special attention to social distance and power and offence severity. The present study differs from other studies that only investigated speech act output by native and non-native speakers of English in that it delineates gender differences in the use of apology strategies by the respondents. It also investigates the frequency of apology strategies types and how they are combined. Specifically, this study aims to provide answers to the following research questions:

1. What are the apology strategies used by Saudi EFL teachers in expressing regret?

2. Does the respondents' gender play a role in their use of apology strategies in English?

\section{Methodology}

\subsection{Respondents and sampling}

The sample of the current study included 30 Saudi EFL teachers in Najran, the Kingdom of Saudi Arabia (KSA), who 
were divided into 15 males and 15 females. At the time of data collection, the 30 Saudi EFL teachers were employed in both the Ministry of Education and Najran University. They are all qualified teachers teaching at secondary schools and at university level specialized in the teaching of English as a foreign language. They also have teaching experience at other educational levels such as primary and preparatory schools. Their English proficiency levels range from upperintermediate to advanced levels. They have never practised English in any of the English native-speaking countries as their study, training and experience were conducted in the KSA.

\subsection{Data collection instrument}

With regard to data collection instruments, Blum-Kulka and Olshtain (1984) have emphasized the need for what they term "an empirical design" in order to explain the cross-cultural differences (natives and non-natives), learner differences (males or females), and differences that exist in situations that require an expression of apology. Therefore, the present study used a Discourse Completion Test (DCT) for the purpose of eliciting data, because the DCT helps achieve its aims and accounts for these previously mentioned differences. Kasper and Dahl (1991) defined the DCT as a questionnaire which contains descriptions of certain situations and has the aim of urging the respondents to provide appropriate and specific speech acts for those situations. The current study has adopted the test originally created by Bergman and Kasper (1993), which is mainly appropriate for cross-cultural pragmatic studies. The same test was applied by Nureddeen (2008). All situations, except 6 and 9, are designed by Bergman and Kasper (1993). Situations 6 and 9 are adopted from the CCSARP carried out by Blum-Kulka and Olshtain (1984). The questionnaire is based on role-play written situations where the respondents are asked to complete ten different situations covering six different kinds of apology strategies and their sub-categories (see Appendix A), namely: IFID; Upgrader; Taking on responsibility (self-blame, lack of intent, admission of fact); downgrading responsibility (excuse, justification, claiming ignorance, problematizing a precondition, denial, reducing severity of offence); offer of repair; and verbal redress. Before the respondents embarked on responding to the DCT, they were asked to fill in certain personal information related to their names/initials, email addresses (optional choice), gender, nationality and for how long and where they have studied English. The respondents were also asked to specify whether or not they have been to an English nativespeaking country. Although a pilot study is usually conducted in cross-cultural pragmatic studies in order to verify the reliability and validity (both internal and external) of the data collection instrument, this did not occur here, because the reliability and validity of the DCT are certified in other studies (Kasper \& Dahl, 1991; Beebe \& Cummings, 1995).

\subsection{Procedures}

In the questionnaire used in the present study, the respondents were asked to interact with the situations by imagining that they belong to different social statuses whether higher, lower or equal. In addition, social distance and power have affected the ten situations included in the test used in this study. Closeness, distance (i.e. strangers) and middle relationship status, as the three different levels of social distance depicted here, are observed in the construction of the 10 situations. Furthermore, the different levels of power, i.e. high-low, low-high and equal, are also indicated in the test. Situations 1 and 2 reflect the equal status of both interlocutors and their close relationship. Whereas situation 3 reflects that the apologizer belongs to a high-low social status with a relationship of acquaintance, situation 4 reflects the fact that the apologizer is affiliated to a low-high social status with a relationship of acquaintance. Situations 5 and 6 reflect a distant relationship between the two interlocutors who have equal social status. In contrast, situations 5 and 6 , and situations 7 and 8 reflect a relationship of acquaintance between two interlocutors who have equal social status. Situation 9 indicates that the apologizer belongs to a high-low status with a distant relationship between the two interlocutors. Finally, situation 10 differs from 9 in that it indicates that the apologizer belongs to a low-high social status and a distant relationship exists between the two interlocutors. Nureddeen (2008) found that the severity of offences included in the 10-situation questionnaire can be classified as either mild or serious. The judgment of this type of classification can be done without reference to the offence context. For example, the severity of offence is serious in situation number 1 (damaged car), whereas it is mild in situation number 2 (damaged magazine). In all situations with the exceptions of 3 and 8, offences damaged the negative face of the hearer. However, in situations 3 and 8 the damage resulted from the two offences are related to the positive face of the hearer. The variables which were taken into account in the DCT utilized in the current study are provided in Table 1 below:

Table 1. Variables of the ten situations as adopted from Nureddeen (2008: 297)

\begin{tabular}{ccccccc}
\hline No. & Situation & Distance & Power & Severity & $\begin{array}{c}\text { Type of } \\
\text { Offense }\end{array}$ & $\begin{array}{c}\text { H's damaged } \\
\text { faced }\end{array}$ \\
\hline 1 & Damaged car & Close & Equals & Serious & Possession & - \\
\hline 2 & Damaged magazine & Close & Equals & Mild & Possession & - \\
\hline 3 & Failed student & Acquaintances & High-Low & Serious & Integrity & + \\
\hline 4 & Borrowed book & Acquaintances & Low-High & Mild & Possession & - \\
\hline 5 & Wrong office & Distant & Equals & Mild & Place & - \\
\hline 6 & Falling bag & Distant & Equals & Serious & Physical & - \\
\hline 7 & Delayed message & Acquaintances & Equals & Mild & Possession & - \\
\hline 8 & Borrowed money & Acquaintances & Equals & Serious & Integrity & + \\
\hline 9 & Late for interview 1 & Distant & High-Low & Serious & Time & - \\
\hline 10 & Late for interview 2 & Distant & Low-High & Serious & Time & - \\
\hline
\end{tabular}


This study, as opposed to others conducted on Arab speakers' apology strategies (e.g. Nureddeen, 2008; Al-Sobh, 2013 and Al-Zumor, 2011) or on non-native speakers and English native speakers (e.g. Iragui, 1996; Gonda, 2001; and Demeter, 2006) does not translate the DCT into the mother tongue of the Saudi respondents because they are all English language teachers who can understand and respond to the ten situations.

\subsection{Data analysis}

The study uses an analysis of frequency and percentage similar to the analysis used in other studies in this field (e.g. Blum-Kulka \& Olshtain, 1984; Hussein \& Hammour, 1998; Lorenzo-Dus, 2001; Bataineh \& Bataineh, 2006; Nuredden, 2008; Al-Zumor, 2011; Afghari \& Karimnia, 2012; Jones, 2013 among others). As a quantitative descriptive research study, data collection has relied on the DCT which has had its reliability, and internal and external validity verified. Three categories of variables (binary, nominal and ordinal) have been investigated. While the binary variables refer to male and female, the nominal category refers to the Arabic and English languages. Ordinal variables include the most frequent apology strategies used by the respondents. The present study is quantitative insofar as it employs quantitative descriptive statistics (i.e. frequency analysis and percentages) to analyze the data, answer the research questions and indicate the types of apology strategies that are frequently used by the respondents. The researcher tabulated the responses in order to identify the apology strategies which have been used. This method helps verify the appropriateness of applying Bergman and Kaspers' model to the respondents' apology strategies (Bataineh \& Bataineh, 2006 and Nureddeen, 2008). In section 4, the responses to each situation by the respondents are classified in terms of the kinds of apology strategies involved. The percentage of the respondents who are using each kind of apology strategy in each situation is calculated. Then, the total number of respondents using each strategy in the ten situations and their percentage are calculated. These results are presented and discussed in the next section.

\section{Results and discussion}

\subsection{Results}

Table 2 shows the frequency and percentage of the kinds of apology strategies used by the thirty respondents (i.e. Saudi EFL respondents).

Table 2. Analysis of frequency and percentage of apology strategies used by 30 Saudi EFL respondents

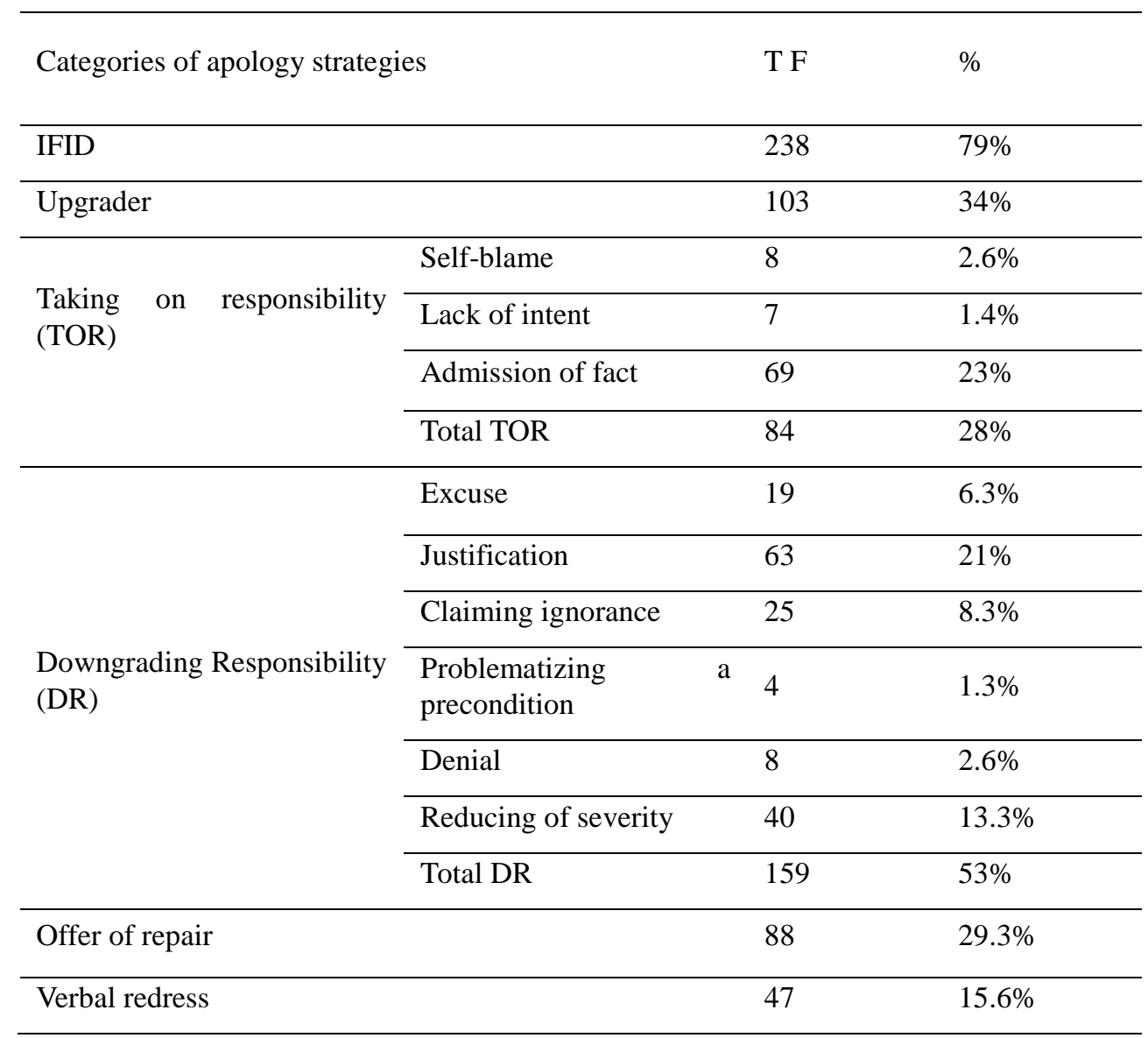


Table 3 presents the frequency and percentage of apology strategies by the fifteen Saudi male respondents. Similar information for their fifteen Saudi female counterparts is demonstrated in Table 4.

Table 3. Analysis of frequency and percentage of apology strategies used by 15 Saudi EFL male respondents

\begin{tabular}{|c|c|c|c|}
\hline \multicolumn{2}{|l|}{ Categories of apology strategies } & $\mathrm{T} F$ & $\%$ \\
\hline \multicolumn{2}{|l|}{ IFID } & 130 & $86.6 \%$ \\
\hline \multicolumn{2}{|l|}{ Upgrader } & 64 & $42.8 \%$ \\
\hline \multirow{4}{*}{ Taking on responsibility (TOR) } & Self-blame & 4 & $2.6 \%$ \\
\hline & Lack of intent & 3 & $2 \%$ \\
\hline & Admission of fact & 28 & $18.6 \%$ \\
\hline & Total TOR & 35 & $23.3 \%$ \\
\hline \multirow{7}{*}{ Downgrading Responsibility (DR) } & Excuse & 8 & $5.3 \%$ \\
\hline & Justification & 29 & $19.3 \%$ \\
\hline & Claiming ignorance & 8 & $5.3 \%$ \\
\hline & $\begin{array}{l}\text { Problematizing a } \\
\text { precondition }\end{array}$ & 4 & $2.6 \%$ \\
\hline & Denial & 4 & $2.6 \%$ \\
\hline & Reducing of severity & 18 & $12 \%$ \\
\hline & Total DR & 71 & $47.3 \%$ \\
\hline Offer of repair & & 42 & $28 \%$ \\
\hline Verbal redress & & 25 & $16.6 \%$ \\
\hline
\end{tabular}

Table 4. Analysis of frequency and percentage of apology strategies used by 15 Saudi EFL female respondents

\begin{tabular}{|c|c|c|c|}
\hline Categories of apology strategies & & $\mathrm{T} F$ & $\%$ \\
\hline IFID & & 108 & $72 \%$ \\
\hline Upgrader & & 39 & $26 \%$ \\
\hline \multirow{4}{*}{ Taking on responsibility (TOR) } & Self-blame & 4 & $2.6 \%$ \\
\hline & Lack of intent & 4 & $2.6 \%$ \\
\hline & Admission of fact & 41 & $27.3 \%$ \\
\hline & Total TOR & 49 & $32 \%$ \\
\hline \multirow{7}{*}{$\begin{array}{l}\text { Downgrading Responsibility } \\
\text { (DR) }\end{array}$} & Excuse & 11 & $7.3 \%$ \\
\hline & Justification & 34 & $22.6 \%$ \\
\hline & Claiming ignorance & 17 & $11.3 \%$ \\
\hline & $\begin{array}{l}\text { Problematizing a } \\
\text { precondition }\end{array}$ & 0 & $0 \%$ \\
\hline & Denial & 4 & $2.6 \%$ \\
\hline & Reducing of severity & 22 & $14.6 \%$ \\
\hline & Total DR & 78 & $52 \%$ \\
\hline Offer of repair & & 41 & $27.3 \%$ \\
\hline Verbal redress & & 22 & $14.6 \%$ \\
\hline
\end{tabular}

As shown in Table 2, the percentages of the TF of all apology strategies used by the Saudi respondents are as follows: IFID (79\%), upgrader (34\%), taking on responsibility (28\%), downgrading responsibility (53\%), offer of repair $(29.3 \%)$, and verbal redress $(15.6 \%)$. This indicates that IFID is the most used apology strategy by the Saudi respondents followed by downgrading responsibility, upgrader, offer of repair, taking on responsibility and finally verbal redress. With regard to the gender effect on using apology strategies among the Saudi respondents, Table 3 indicates that IFID is the most used apology strategy by the Saudi male respondents (80\%), followed by upgrader $(43 \%)$. Both downgrading responsibility and offers of repair have the same percentage (28\%), followed by taking on responsibility $(23.3 \%)$ and finally verbal redress (16.6\%). The results of Table 4 confirm that IFID is the most used apology strategy by the Saudi female respondents (72\%). This is followed by downgrading responsibility (58\%), taking on responsibility $(32 \%)$, offers of repair $(27.3 \%)$, upgrader $(26 \%)$, and verbal redress $(14.6 \%)$. This comparison indicates as well that the Saudi males outperform their female counterparts in using the apology strategy of IFID (80\% vs. $72 \%$ ). Although the Saudi females tend to downgrade their responsibility, by using the second highest adopted apology strategy (58\%), their male counterparts tend to employ upgrader as the second most used strategy (43\%). In addition, the Saudi females had a higher percentage of taking on responsibility $(32 \%)$ than their male counterparts $(23.3 \%)$ did. Saudi females also have exceeded Saudi males in using the strategy of downgrading responsibility $(53 \%$ vs. $28 \%$ ). However, the Saudi males slightly outperformed their female counter parts in using the strategy 'offer of 
repair' ( $29 \%$ vs. $28 \%$ ). For both Saudi male and female respondents, verbal redress is the least adopted apology strategy (16.6\% vs. $14.6 \%)$ even though males slightly outperform their female counterparts in adopting a verbal redress strategy. The results of each apology strategy adopted by both male and female Saudi EFL teachers are presented separately in the following subsections:

\subsubsection{IFID}

As shown in Table 2, the Saudi respondents have explicitly expressed their apology by using the IFID apologetic expressions such as 'sorry, forgive me' $(79 \%)$. In the ten situations, the frequency of using the IFID strategy by the Saudi respondents ranges from $14(46 \%)$ to $28(93 \%)$. The percentage of IFID frequency exceeds 70 per cent in all situations with the exception of situation three (46\%). In terms of the severity of offence explained in Table 1 , Table 2 shows that among all situations in which the degree of offence severity is rated as serious (situations 1, 3, 6, 8, 9, 10), situation three (failing student) has the lowest percentage of IFID frequency (46\%) in spite of the fact that it represents the most serious offence. Situations 5 (wrong office), 6 (falling bag), and 10 (late for interview 2) have the highest frequency percentage of using IFID among the Saudi respondents although the offender and the offended person in the three situations represent different extents of social distance and have different amounts of power. In Situation 5 (which involves mild offence), the offender and victim have equal power, whereas in situation 10 the offender has low power over the victim. Situations 2 (damaged magazine), 4 (borrowed book) and 7 (delayed message) which represent mild offences, different social distance and power have high frequency percentages of using IFID. Situation 4 (which reflects low-high power) and situation 7 (which reflects equal power) have higher frequency percentages $(80 \%$ each) than situation 2, which reflects equal power between the offender and the victim (73\%). Situations $5(90 \%), 6(93 \%), 9$ (73\%), and $10(93 \%)$, which represent distant social relations between the offender and the victim, have high percentages of IFID frequency (with the exception of situation 9 where frequency is $73 \%$ ).

Table 3 indicates that $80 \%$ of Saudi male respondents have used an IFID strategy. Their frequency ranges from 10 $(67 \%)$ to $15(100 \%)$. In terms of serious offence situations, Saudi males use a high frequency of IFID in situations $(1,3$, $6,8,9,10)$ with situation 10 having the highest IFID frequency $(100 \%)$ and situation 3 having the lowest IFID frequency $(67 \%)$ although these situations represent different social distances and powers. Whereas situation 3 reflects high-low power between the offender and the victim, situation 8 reflects equal power. In terms of mild offences, Saudi males have a high percentage of IFID use frequency in situations $2(80 \%), 4(93 \%), 5(87 \%)$, and 7 (93\%). Although situations 2, 5, and 7 reflect equal powers between the offender and the victim, situation 4 reflects low-high power between them. They also indicate social relations between the offender and the victim (situations 4 and 7) and close and distant social relations for situations 2 and 5 respectively.

Table 4 shows that Saudi female respondents have used IFID less than their male counterparts (72\%). The range of their IFID frequency is between $4(27 \%)$ in situation 3 which reflects the most serious offence and 14 (93\%) for situations 6 and 10 which reflect serious offences as well, and situation 5 that reflects a mild offence. Situations 5 , 6 , and 10 represent distant social relations between the offender and the victim. Although situation 10 indicates low-high power between the offender and the victim, situation 5 indicates equal power between them. As for the mild offence in situations 2, 4, 5 and 7, Saudi females have a low IFID frequency for situations 2, 4, and 7 (67\% each) while they have one of the highest IFID percentages (93\%) in situation 7.

Based on the responses to the DCT, the Saudi respondents have tended to employ an IFID strategy in various forms, namely singly or combined with other strategies. For examples, the first Saudi female respondent has replied to situation 4 by saying "I am sorry (IFID), I forgot it at home (admission of fact), I should not have done so" (self-blame). She has replied to situation 5 by saying "excuse me (IFID), is it Layan's office? (reducing severity). For situation 6, the same respondent has said "I am sorry (IFID), it is my fault" (self-blame). The same respondent, however, has used an individual form of IFID in replying to situation 8 by saying "I am sorry, Sami". Similarly, the first Saudi male respondent has used an individual form of IFID in responding to situation 3 by saying "I do apologize for this big mistake". The same respondent, however, has used a combined form of IFID when responding to situation 5 by saying "I beg your pardon (IFID); I am looking for Layan (justification)". In responding to situation 6, the same Saudi male respondent has said "excuse me (IFID), it is my fault (self-blame)". In addition, some of the Saudi respondents have started and finished their apology by using IFID strategies. For example, the third Saudi female respondent has replied to situation 1 by saying "I am sorry (IFID), I hit a lamppost (justification) and damaged the car (admission of fact), forgive my carelessness (IFID)". The responses of the Saudi respondents (both males and females) indicate that most have given a full explanation while expressing their apology and only a very few have provided short expressions of apology.

\subsubsection{Upgrader}

The frequency percentage of using upgraders by the Saudi respondents is $34 \%$. Thus, the percentage of upgrader frequency ranges from $4(13 \%)$ in situation 3, (which reflects the most serious context of offence and low-high power between the offender and the victim), to $16(53 \%)$ in situations 2 and 8 . Although situation 2 indicates equal power between the offender and the victim, a mild context of offence and close social relations between them, situation 8 involves a serious offence in a context of equal power and social acquaintance between the parties. For other serious offence situations (6, 9 and 10), the Saudi respondents have a high frequency of using upgraders (40\%) for situation 6 and $43 \%$ for situation 10, while showing a lower percentage in situation $9(26 \%)$. The percentage of upgrader frequency used by all Saudi respondents is situations 1 (damaged car) and 4 (borrowed book) are the same (23\% each) although both represent different degrees of severity, different social distances and different power. Whereas situation 1 reflects a 
serious degree of offence severity, close social distance and equal power, situation 4 represents a mild degree of offence severity, acquainted social distance and low-high power (see Table 2).

As for the Saudi male respondents, the use of an upgrader strategy has the second highest percentage of frequency after IFID (43\%). The range of upgrader percentage of frequency ranges between $4(27 \%)$ and $9(60 \%)$. With regard to situations $(1,3,6,8,9$, and 10), which reflect serious degrees of offence, Saudi males have a low frequency percentage of using an upgrader strategy in situations 1 (damaged car), 3 (fail student) and 9 (late for interview 1). While situation 1 represents close social distance and equal power, situation 3 involves social acquaintance and high-low power while situation 9 reflects distant relations and high-low power. In other serious offence severity situations $(6,8$, and 10), Saudi males have a higher frequency percentage of using an upgrader strategy $(53 \%, 40 \%$ and $60 \%)$. The highest percentage of using an upgrader occurs in situation 10 , which reflects a serious degree of offence severity, distance social distance and low-high power between the apologizer and the victim, as shown in Table 3.

Regarding Saudi female respondents, the use of the upgrader comes in fifth place among other apology strategies (26\%). The frequency percentage of employing upgraders among females ranges between $0 \%$ (situation 3 ) and $67 \%$ (situation 8). For serious offence situations, Saudi females display the percentages of 20\%, 0\%, 27\%, 67\%, 27\% and $27 \%$ for situations $1,3,6,8,9$ and 10, respectively. Therefore, the highest percentage (67\%) of using an upgrader strategy occurs in situation 8 (borrowed money), which reflects acquaintance and equal power between the offender and the victim. The lowest upgrader percentage occurs in situation 3 (failed student), which represents acquaintance and high-low social power. Concerning the mild offence of severity situations (2, 4, 5, and 7), Saudi females have a low frequency percentage of using an upgrader strategy $(47 \%, 20 \%, 13 \%$ and $13 \%)$ successively. These situations of mild offence of severity represent different social distances and powers (see Table 4).

With regard to the upgrader formula, the majority of Saudi respondents have adopted a single type of upgrader, such as "I am really sorry", "I am terribly sorry", "I'm genuinely sorry" and "I am so sorry". On the other hand, some of the Saudi respondents, mostly males, have adopted a combined formula of upgrader such as "I'm extremely sorry for being late. It's because of the traffic jam" (i.e. upgrader + justification), "I am so sorry to disturb you. I thought this office was Layan's" (i.e. upgrader + downgrading responsibility in terms of claiming ignorance), "I am terribly sorry my son found it in my drawer and tore the cover page. I am really sorry. Where did you buy it? I will buy you a new one (i.e. upgrader + excuse + upgrader + reducing severity + offer of repair).

\subsubsection{Taking on responsibility (TOR)}

The overall percentage of employing the apology strategy TOR by the Saudi respondents is $28 \%$. As described in Table 2, the percentage of TOR frequency falls to between $0 \%$ (situation 10) and 63.3\% (situation 4). Regarding situations (1, $3,6,8,9$, and 10), which reflect serious offences, the Saudi respondents have high frequency percentage in situations 1 (20\%), $3(33 \%), 6(80 \%)$ and $8(23.3 \%)$ where the apologizers and the victims have equal power (6 and 8$)$ but are of high-low power in 3 . They have acquainted social relations in situations 3 and 8 and distant social relations in situation 6. With respect to situations 2, 4, 5 and 7, which represent mild degrees of offence severity, the Saudi respondents show a low percentage of using a TOR in both the damaged magazine situation (3\%), and the wrong office situation (16\%). Situations 2 and 5 show equal power between the apologizers and their victims but a different social distance between them: close in the first and distant social distance in the second, respectively. However, the Saudi respondents have a high percentage of using TOR in situations $4(63.3 \%)$ and $7(50 \%)$. The highest percentage of TOR occurs in situation 4 (borrowed book) which represents acquainted social relations and low-high power. The percentage frequency of TOR strategy used by Saudi males, as shown in Table 3, is $23.3 \%$ with a range from $0 \%$ to $46 \%$. In terms of the degree of offence severity, Saudi males have a low percentage frequency of using the TOR strategy in situations 1 and 3 (20\% each), and $9(13 \%)$. Whereas situation 1 reflects close social relations between the apologizer and the victim, 3 involves acquainted social relations. Situation 9 indicates distant social relations and high-low power between the offender and the victim. The Saudi males have a high frequency percentage of employing TOR in situations 6 , and 8 (40\% each) although both situations reflect different social distance (distant and acquainted); participants are of equal power. Their lowest percentage of TOR use occurs in situation $10(0 \%)$. Saudi males only have a high percentage of using TOR in situations $4(46 \%)$ and $7(40 \%)$ of mild offence of severity. Their lowest percentage of using TOR occurs in situation 2 $(0 \%)$ which reflects close social relations and equal power in contrast to situation 4, which presents low-high power between the offender and the victim. For other mild offence situation (wrong office), Saudi males have a low percentage of using TOR strategy (13\%) as the offender and the victims are of equal powers although they have distant social relations. Saudi females, in contrast, have a higher percentage of employing a TOR strategy (32\%). Their TOR percentage ranges between $(0 \%)$ and $(80 \%)$. Their highest percentage of using TOR $(80 \%)$ occurs in situations 4 and 6 . These two situations reflect a mild offence and a serious offence context. Whereas situation 4 reveals low-high power between the offender and the victim, situation 6 indicates equal power between them. Similar to their male counterparts, the lowest percentage of Saudi females occurs in situation $10(0 \%)$.

\subsubsection{Downgrading responsibility (DR)}

The Saudi respondents have the second highest percentage of using apology strategies when employing downgrading responsibility (DR) strategies (53\%). The frequency percentage of using DR by Saudi respondents ranges between $13.3 \%$ and $93.3 \%$. As for contexts involving serious offence, the Saudi respondents' highest percentage of DR strategies is in situations 1 (66.6\%) (equal power, close relation), 3 (46.6\%) (high-low power and acquainted relation), 8 (53.3\%) (equal power, acquainted relation), 9 (53.3\%) (high-low power and distant relation) and 10 (90\%) (distant relation and low-high power), while their lowest percentage of DR strategies occurs in situation 6 (13.3\%) (equal power and distant 
relation). This suggests that Saudi respondents have a tendency to downgrade their responsibility when the offender and victim are strangers and the former has less power than the victim (late for interview 2). This is affirmed by their lowest DR percentage in the falling bag situation (see Table 2).

By gender, the DR percentage of Saudi male respondents is $28 \%$. Their DR percentage ranges between $20 \%$ and $86.6 \%$. The highest DR percentage of Saudi males occurs in situation 10 where there is low-high power and distant relation between the apologizer and the victim. Their lowest DR percentage occurs in situation 6 where the power of the offender and the victim is equal and they are strangers. For the four mild offence situations, the highest DR percentage (86.6\%) of Saudi males exists in situation 5 where the offender and victim are strangers and they are equal in power, while their lowest DR percentage (20\%) occurs in situation 4, where the apologizer and victim are acquainted but the former is lower in power than the victim (Table 3). In addition, the DR percentage of Saudi females is (58\%). Their DR percentage falls to between $(6.6 \%)$ and $(80 \%)$, as shown in Table 4 . In terms of serious contexts of offence, their highest DR percentage (80\%) occurs in situation 1, where the apologizer and the victim are socially close and they have equal power, while their lowest DR percentage (6.6\%) occurs in situation 6, where the offender and the victim are strangers and have equal power.

\subsubsection{Offers of repair}

The overall percentage of offers of repair strategy used by Saudi respondents is (29\%.3). It ranges from 3.3\% to $96 \%$ as displayed in Table 2. With regard to offence severity in the six serious offence situations, Saudi respondents have the highest percentage of offers of repair (96\%) in situation 1, where the offender and the victim are close in their social relations and have equal power. They show a $60 \%$ frequency (fail student) where the offender and victim are acquainted and the offender has higher power than the victim and 10\% for situation 6 where the offender and the victim are equal in power but distant in their relation. This means people are more likely to offer repair when they have close social relations than when they are strangers in order to maintain that social relation. For situations 8 and 9, the Saudi respondents have the same percentage frequency (13.3\%). For situation 10, although the offender is lower in power than the victim and they are not socially close, the Saudi respondents show a low percentage in using the offer of repair strategy $(6.6 \%)$. For the four mild offence situations $(2,4,5$ and 7$)$, the Saudi respondents have a high percentage of offering repairs in situations 4 and 7 as the offender and the victim are socially acquainted even though the offender and the victim are equal in power in situation 7 and they have low-high power in situation 7 . On the other hand, the Saudi respondents have an average percentage of using this strategy in situation $2(30 \%)$ and the percentage in situation 5 $(3.3 \%)$ where the apologizer and the victim are socially distant (see Table 2 ).

The percentage of using offer of repair strategy by the Saudi males is $28 \%$. The offer of repair percentage of Saudi males ranges from $0 \%$ in situations 5, 6, 9 and 10, (socially distant), to $73 \%$ in situation 4 , where the offender the victim are socially acquainted. The percentage of using an offer of repair strategy by the Saudi females is $27.3 \%$ and ranges between $6.6 \%$ and $53 \%$. The highest use of offer of repair occurs in situation 3 and the lowest in situation 5 . The offender and victim are socially acquainted in situation 3 , but they are socially distant in situation 5 . Their percentage of using offer of repair strategy is $4.1 \%$.

\subsubsection{Verbal redress}

The frequency percentage of verbal redress among the Saudi respondents is $(15.6 \%)$. The verbal redress percentage, according to Table 2, ranges between $0 \%$ and $40 \%$ for the falling bag situation. In terms of severity of offence, the Saudi respondents show an inclination to use this strategy in situations 8, 9 and 10 (23.3\%), where there is a distant social relation in the latter two situations between the offender and the victim. These situations also represent varying degrees of power, i.e. equal for situation 8, high-low for situation 9 and low-high for situation 10. Regarding the four mild offence situations, the Saudi respondents show $10 \%$ use in situation 2, 3.3\% use in situations 4 and 5, and 30\% use in situation 7. The highest percentages of using verbal redress among Saudi respondents occur in situation 6 (40\%) where there is a distant social relation between the offender and the victim. This is followed by situation 7 (30\%) where the apologizer and the victim are acquainted. In both situations, the two parties are of equal power, as shown in Table 2.

In addition, the Saudi males' percentage of using verbal redress is $(16.6 \%)$. It ranges between ( $0 \%)$ for situations 1,3 and 4 and (46.6\%) for situation 6 (see Table 3). The percentage of using verbal redress by Saudi females is $14.6 \%$ and ranges from $0 \%$ to $26.6 \%$ (see Table 4). For the six situations of serious offence of severity, the percentage differs: it is 0 in situations 1 and 3,33\% for situations 6 and 9,20\% for situation 8 and 26.6\% for situation 10. The highest verbal redress percentage shown for Saudi females exists where there is a distant social relation (situations 6 and 9) between offender and the victim although in the former there is high-low power and in the latter there is low-high power between the offender and the victim. For the four involving mild offence severity, the verbal redress percentages of Saudi females are 6.6\% (situation 2), 6.6\% (situation 4), $0 \%$ (situation 5), and 20\% (situation 7). The next section provides a discussion of these results.

\subsection{Discussion}

Out of all apology strategies, IFID is the most used apology strategy by both males and female Saudi respondents. This finding is similar to the results reported by Bataineh et al. (2005), Bataineh \& Bataineh (2006), Al-Zumor (2011) and Al-Sobh (2013). This result reflects the influence of interlanguage pragmatics in selecting the most appropriate apology strategy. It shows how Saudi respondents are positively influenced by their mother tongue transfer into their foreign language output as they opt to choose the direct expression of apology based on their cultural habits (Farashaiyan \& Amirkhiz, 2011). In other words, the Saudi respondents have adopted IFID as the most direct way to realize an apology. 
The adoption of IFID formulae of apology reveals that the Saudi respondents explicitly perform apology by using verbs of apology such as "be sorry", "excuse me", and "pardon me". The adoption of IFID strategy by Saudi respondents confirms the definition of the IFID strategy introduced by Cohen and Olshtain (1985). The Saudi respondents have employed various IFID formulae. They have expressed their regret by using the direct IFID formula of apology "I am sorry" and offered their apology (e.g., I apologize). These two formulae are compatible with the results reported by Blum-Kulka and Olshtain (1984).

In addition, the Saudi respondents have employed the IFID formula of requesting forgiveness from their victims by using expressions like "excuse me", "please, forgive me" and "pardon me". This result is similar to the results reported by Cohen (1999). In this respect, Bergman and Kasper (1993) have explained that "excuse me" is a remedial formula of apology that gives remedy for a wrongdoing. Therefore, the Saudi respondents have attempted to mitigate their offences by providing verbal and remedial compensation to their victims. Furthermore, the Saudi respondents have tended to combine an IFID strategy with other strategies. This combined formula reveals their belief that the construction of apology expression should comprise IFID as a compulsory component followed by another type of apology strategy. This result confirms the result reported by Abu-Humei (2013).

With respect to offence severity, the Saudi respondents have a high percentage of IFID strategy use in all situations in which the degree of offence severity is classified as serious with the exception of situation 3 (failing student). They have employed the highest frequency of IFID use to situations 5,6 and 10, which reflect different social distance and powers. This result confirms that reported by Nureddeen (2008). In terms of gender, both Saudi male and female respondents have the highest percentage of adopting the IFID strategy of all available strategies of apology. There is a slight difference in this regard in favor of the Saudi male respondents over their female counterparts. This result is similar to that reported by Bataineh \& Bataineh (2006).

As reported in section 4.1.2, an upgrader is found to be the third apology strategy used by the Saudi respondents in terms of its frequency. The overall percentage of using upgraders by the Saudi respondents resembles the results reported by Al-Sobh (2013) of Jordanians using intensifiers. In other words, the Saudis like the Jordanians, use more intensifiers whenever there is distant social distance and low-high power. The adoption of upgraders in such cases is attributed to cultural reasons as the Arab culture necessitates the use of such intensifiers as a sign of showing respect to the interlocutors (Nureddeen, 2008). The Saudi respondents have opted to use an upgrader strategy (i.e. intensification marker + IFID) in order to add to the apologetic power of their apology. This intensification involves, according to Blum-Kulka and Olshtain (1984), the use of adverbials such as "terribly, very, so, extremely" in addition to the IFID strategy. In addition, the Saudi respondents have provided single and combined formulae of using the upgrader strategy. The Saudi respondents are similar to the Sudanese respondents studied by Nureddeen (2008) in applying various formulae in their use of upgrader strategies. It is remarkable that the Saudi respondents have tended to adopt long apology strategies, such as the case of using a combined upgrader strategy whenever there is a close social distance between the offender and the victim as a means of face-saving on the part of the apologizer; this is in accordance with Arab culture. This result is similar to that reported by Gonda (2001). The Saudi respondents have tended to have a high percentage of upgrader frequency in situations which reflect serious offences of severity, including falling bags and borrowed money; for situations of mild offence, Saudi respondents are likely to use upgrader strategies in situation 2 (damaged magazine; the highest percentage) and situation 7 (delayed message). However, for situations 4 and 5, the Saudi respondents indicate an average percentage of using upgraders (23\% and 26\%). This result is similar to that reported by Nureddeen (2008). The effect of gender on using the upgrader strategy among Saudi respondents shows a substantial difference between Saudi males (43\%) and females (26\%). Saudi females use fewer intensifiers as compared to their male counterparts, a practice that may stem from their cultural backgrounds as they want to avoid getting involved in discussion over their wrongdoings. This result resembles that reported by Bataineh \& Bataineh (2006).

As shown in section 4.1.3, the adoption of TOR ranks fifth for the Saudi respondents among all other apology strategies. This is attributed to the fact that very few Saudi respondents have adopted "self-blame" and "lack of intent" strategies. In a reflection of the mother tongue cultural influence, the result confirms findings reported by Bataineh and Bataineh (2006) in the sense that Saudi like their Jordanian counter parts are less inclined to adopt these strategies. In terms of severity of offence, the Saudi respondents have the highest TOR percentage when the apologizer has less power than the victim although they are socially acquainted. This result reflects the cultural impact of the respondents' mother tongue on their adoption of an apology strategy and the foreign language output. The result is similar to those reported by Al-Sobh (2013) and (Farashaiyan \& Amirkhiz, 2011). The use of a TOR strategy varies among Saudi respondents according to their gender as Saudi females have used a TOR strategy (32\%) more than their male counterparts (23.3\%). The result resembles that reported by Bataineh and Bataineh (2006).

According to the results shown in section 4.1.4, DR strategies rank second among the apology strategies used by the Saudi respondents. This result is compatible with those reported by Trosborg (1985) and Holmes (1989). In terms of offence severity, Saudi respondents are more inclined to downgrade their responsibility whenever the apologizer has less power than the victim and they have a distant relation (situation 10). Thus, when they are equal in power and have a distant relation, the Saudi offenders have the lowest percentage of downgrading their responsibility towards their victims (situation 6 falling bag). The result is similar to those of the study conducted by Al-Sobh (2013) and (Farashaiyan \& Amirkhiz, 2011). With respect to gender, Saudi females outperform their male counterparts in downgrading their responsibility, particularly when the offender and victims are closely related and have equal power as they then dare to argue with them. But this is not their case when the offender and the victim are strangers as here Saudi 
females have the lowest percentage of downgrading their responsibility of the wrongdoing in an attempt to absorb the anger of their victims (situation 6 falling bag). This result reflects the cultural influence of the mother tongue over the foreign language output (i.e. the interlanguage pragmatics). The result resembles those conveyed by Bataineh and Bataineh (2006) and Nureddeen (2008).

As reported in section 4.1.5, the overall percentage of offer of repair strategy suggests that it ranks fourth among apology strategies used by Saudi respondents. Based on severity of the offence, the Saudi respondents have the highest percentage of offers of repair when the offender and the victim are socially close in an attempt to sustain and maintain that social relation. But when the offender and the victims are socially distant, the Saudi respondents have lower percentages of using the offer of repair strategy. This result is mainly explained in terms of the respondents' cultural background as they offer repairs whenever they are closely associated with the victims to sustain the social relation. The result is similar to those reported by Nureddeen (2008) and Al-Zumor (2011). In terms of gender, Saudi males are more to adopt the offer of repair strategy than females. However, a gender-based difference is not significant given the percentages. This result is similar to that reported by Bataineh and Bataineh (2006).

Finally, based on section 4.1.6, verbal redress is the apology strategy least used by the Saudi respondents. This result is similar to that reported by Farashaiyan and Amirkhiz (2011) and Al-Sobh (2013). In terms of offence severity, the Saudi respondents tend to use a verbal redress strategy whenever the offender and the victim are of equal power, although they may be either socially distant or socially acquainted. Therefore, it is the type of power involved that influences the use of verbal redress among the Saudi respondents. The result is similar to that reported by Nureddeen (2008). In terms of gender, although the male Saudi respondents have had higher percentages of using this strategy, the difference is insignificant. The result is similar to those reported by Cameron (1997) and Bataineh and Bataineh (2006).

\section{Conclusion and recommendations}

This study has investigated the apology strategies used by 30 Saudi EFL teachers in Najran, the Kingdom of Saudi Arabia (KSA), taking into account variables such as social distance and power and offence severity. The study has also examined the influence of the participants' gender on their use of apology strategies in English. To achieve this, the study utilized a DCT that includes 10 situations designed to test how the respondents would react if they imagine that they belong to different social statuses whether higher, lower or equal. Additionally, social distance and power have been taken into consideration in designing the ten situations included in the test used in this study. The results reveal that the most used apology strategy by the Saudi respondents is Illocutionary Force Indicating Device (IFID) followed by downgrading responsibility, upgrader, offer of repair, taking on responsibility and then verbal redress. It has been argued that some of the respondents' results reflect the cultural influence of the mother tongue over the foreign language output (i.e. interlanguage pragmatics). The results also demonstrate that gender has a great impact on the use of apology strategies in various ways. Both Saudi male and female respondents have the highest percentage of adopting the IFID strategy of all available strategies of apology. The effect of gender on using the upgrader strategy among Saudi respondents is very obvious; there is a substantial difference between Saudi males (43\%) and females (26\%). The results also show that Saudi females outperform their male counterparts in downgrading their responsibility, particularly when the offender and victims are closely related and have equal power as they, then, dare to argue with them. However, that was not noted when the offender and the victim are strangers, since, here, Saudi females have the lowest percentage of downgrading their responsibility of the wrongdoing in an attempt to absorb the anger of their victims. Such a result also reflects the effect of the respondents' first language on their use of the target language. Based on these results, it is recommended that other strategies of English speech acts, such as invitations, expressions of condolence, refusal and request need to be studied in order to have a fuller understanding of how Saudi learners use them and what influence their culture has on their understanding of them. In addition, other social variables such as age, social background and attitudes towards L2 learning need to be examined as well in relation to pragmatic Saudi output. Finally, a contrastive study needs to be carried out between Saudi EFL learners and native speakers of English in order to determine the difference between the two groups in using apology strategies.

\section{References}

Abu-Humei, A. M. A. (2013). The effect of gender and status on the apology strategy used by American native speakers of English and Iraqi EFL university students. Research on Humanities and Social Sciences, 3(2), 145-173.

Afghari, A. \& Karimnia, A. (2012). On apologizing in Persian: A socio-cultural inquiry. Linguistics, 13(3), 697-734.

Al-Sobh, M. A. (2013). An analysis of apology as a politeness strategy expressed by Jordanian university students. International Journal of Humanities and Social Science, 3(2), 150-154.

Altakhaineh, A. R. M. \& Rahrouh, H. N. (2015). The use of euphemistic expressions by Arab EFL learners: Evidence from Al Ain University of Science and Technology. International Journal of English Linguistics, 5(1), 14-21.

Altakhaineh, A. R. M. \& Zibin, A. S. (2014). Perception of culturally loaded words by Arab EFL learners. International Journal of Linguistics, 6(3), 1-22.

Al-Zumor, A.W. Q. G. (2011). Apologies in Arabic and English an interlanguage and cross-cultural study. Journal of King Saud University- Languages and Translation, 23, 19-28.

Austin, J. L. (1975). How to do things with words. Oxford: Oxford university press.

Bataineh, R, F. \& Bataineh, R. F. (2006). Apology strategies of Jordanian EFL university students. Journal of 
Pragmatics, 38, 1901-1927.

Batanieh, R. F. \& Bataineh, R, F. (2005). American university students' apology strategies: An intercultural analysis of the effect of gender, Yarmouk University. Journal of Intercultural Communication, 9.

Beebe, L. M. \& Cummings, L. C. (1995). Natural speech act versus written questionnaire data: How data collection method affects speech act performance. In S.M. Gess and J. Neu (eds.), Speech acts across cultures: challenges to communication in a second language (pp. 65-88). New York: Mouton de Gruyter.

Bergman, M. \& Kasper, G. (1993). Perception and performance in native and non-native apology. In Blum-Kluka, S. \& Kesper, G. (eds.) Interlanguage pragmatics. Oxford: Oxford University Press.

Blum-Kulka, S. \& Olshtain, E. (1984). Requests and apologies: A cross-cultural study of speech act realization patterns (CCSARP). Applied Linguistics, 5(3), 196-213.

Brown, S. \& Attardo, S. (2000). Understanding language structure, interaction and variation: An introduction to Applied Linguistics and Sociolinguistics for non-specialists. Michigan: Michigan University Press.

Cameron, D. (1997). Performing gender identity: Young men's talk and the construction of heterosexual masculinity. In Johnson S. \& Ulrike H. M. (eds.). Language and masculinity (pp. 47-64). Oxford: Blackwell.

Cohen, A. D. \& Olshtain, E. (1981). Developing a measure of socio-cultural competence: The case of apology. Language Learning, 31, 113-134.

Cohen, A. D. \& Olshtain, E. (1985). Comparing apologies across languages. In Jankowsky, Kurt, R. (ed.) Scientific and humanistic dimensions of language (pp.175-183). John Benjamins Publishing Company, Netherlands.

Cohen, J. R. (1999). Advising clients to apologize. California: California University.

Demeter, G. (2006). A pragmatic study of apology strategies in Romanian. Unpublished M.A. dissertation, Oklahoma State University.

Farashaiyan, A. \& Amirkhiz, S. Y. (2011). A descriptive-comparative analysis of apology strategies: The case of Iranian EFL and Malaysian ESL university students. English Language Teaching, 4(1), 224-229.

Fraser, B. (1981). On apologizing. In F. Coulmas (ed.), Conversational routine: explorations in standardized communication situations and prepatterned speech (pp. 259-271). New York: Mouton.

Gonda, T. (2001). The speech act of apology: Apology behaviour of British English and advanced Greek speakers of English. Unpublished Master dissertation, University of Essex.

Holmes, J. (1989). Sex differences and apology. One aspect of communicative competence. Applied Linguistics, 10(2), 192-213.

Hussein, R. F. \& Hammouri, M.T. (1998). Strategies of apology in Jordanian Arabic and American English. Gazer Linguistische Studien, 49, 37-51.

Iragui, J. C. (1996). Requests and apologies: A comparison between native and non-native speakers of English. ATLANTIS, XVIII, 1(2), 53-61.

Jones, J. F. (2013). Investigating apology response strategies in Australian English and Bahasa Indonesia: gender and cultural perspectives. Australian Review of Applied Linguistics, 36(1), 71-101.

Kasper, G. \& Blum-Kulka, S. (eds.) (1993). Pragmatic transfer. Second Language Research, 8, 203-231.

Kasper, G. \& Dahl, M. (1991). Research methods in interlanguage pragmatics. Studies in Second Language Acquisition, 18 (21), 49-69.

Levinson, S. C. (1983). Pragmatics. Cambridge: Cambridge University Press.

Lorenzo-Dus, N. (2001). Compliment responses among British and Spanish University students: A contrastive study. Journal of Pragmatics, 33, 107-127.

Nureddeen, F. A. (2008). Cross-cultural pragmatics: Apology strategies in Sudanese Arabic. Journal of Pragmatics, 40 , 279-306.

Olshtain, E. \& Cohen, A. D. (1983). Apology: A speech act set. In N. Wolfson and E. Judd (eds.) Sociolinguistics and language acquisition (pp. 8-35). Rowley, Newbury House.

Qorina, D. (2012). Realization of apology strategies by English Department students of Pekalongan University. Language Circle Journal of Language and Literature, VII(1), 93-105.

Searle, J. (1969). Speech acts in the philosophy of language. Cambridge: Cambridge University Press.

Thijittang, S. \& Le, T. (2010). Pragmatic strategies of English of Thai university students: Apology speech acts. PhD thesis, University of Tasmania.

Trosborg, A. (1995). Inter-language pragmatics: requests, complaints and apologies. New York: Mouton de Gruyter.

Yule, G. (1996). Pragmatics. New York: Oxford University Press. 
Appendix A

Appendix A: Discourse Completion Task by Saudi EFL participants

(Please note that all information will be handled with high confidentiality)

Name (optional):

Email (optional):....

I have studied English for (years) in.

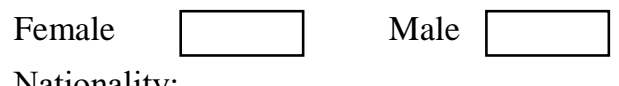

Nationality: ...

Occupation:

Have you ever been to the United Kingdom? Yes / No

If yes, for how long?

Please read the following situations and complete the dialogue using your everyday language. Please respond as realistically and honestly as possible.

1. Khalid and Ahmad are friends. Khalid borrowed Ahmad's car. But while he was backing up, he hit a lamppost and damaged the rear of the car. Khalid is returning the car to his friend.

Ahmad : I Hope you are ok! What happened?

Khalid:

2. Maha and Nada are friends. Maha borrowed a magazine from Nada, but a child at home tore the cover page. Now they are at Nada's home. Maha is giving back the magazine to Nada.

Nada: Oh! What happened to the magazine?

Maha:.....

3. A University teacher mistook one student's exam paper for another due to the similarity in their names and failed him. The teacher knew that he made a mistake, and the student knew what had happened and went to the teacher.

The student: What has happened, Sir?

The teacher:

4. A university student (female) borrowed her teacher's (male) book and promised to return it that day. When she arrived at the university, she discovered that she forgot the book at home. Now she meets her teacher.

The teacher: Have you brought the book?

The student:

5. Lamis wanted to visit Layan in her new office at the University. She went to the University and opened the door of an office, and went in supposing that it was Layan's office, but she discovered that it was somebody else's office (it was Batal's). Lamis and Batal don't know each other. Lamis opened the door and went in suddenly while Batal was writing; he stopped writing and looked up. Lamis knew that it was wrong office.

Lamis:

6. While traveling, Nayef placed a heavy bag on the bus shelf. The bus stopped suddenly and the bag fell on the passenger.

The passenger: Oh God! What was that?

Nayef:

7. Lana and Mohammed are co-workers. Mohammed forgot to pass a private message to Lana - This is the second time he forgets to pass a message on to her. Lana knew Mohammed had a message for her and went to him.

Lana: I've been told that you have a message for me.

Mohammed:

8. Sami denied Soha's allegation that he borrowed money from her and did not give it back. During their conversation, a person came in and told Soha that he was the one who borrowed the money not Sami. 
Sami: (angrily) Do you believe me now?

Soha:.

9. A company manager is supposed to interview a man for a job, but he had been called to unexpected meeting in another place, therefore, he arrived at his office half an hour late.

His secretary: This is Nasser Al Sulayyi. He has been waiting for you for half an hour.

The manager:

10. Ali Al Muneef applied for a job in a factory and had an interview with the manager. He was caught in the traffic jam and arrived half an hour late. Now the secretary takes him into the manager's office.

The secretary: This is Ali Al Muneef.

The manager: You are here at last.

Ali: 